\title{
IAMJ
}

INTERNATIONAL

AYURVEDIC

MEDICAL JOURNAL

$\underline{\text { Review Article }}$

ISSN: 2320-5091

Impact Factor: 6.719

\section{REVIEW ARTICLE ON AYURVEDIC APPROACH SANDHIGAT VATA W.S.R. TO OSTEOARTHRITIS}

\section{S. Tanmane ${ }^{1}$, Akram Yusuf Khan ${ }^{2}$}

${ }^{1}$ Professor \& H.O.D Kayachikitsa Department, Bhausaheb Mulak Ayurved Mahavidyalaya Nagpur, Maharashtra, India

${ }^{2}$ BAMS, MD Ayurveda, PG Scholar Jr 2, Department of Kaychikitsa, Bhausaheb Mulak Ayurved Mahavidyalaya Nagpur, Maharashtra, India

Corresponding Author: dr.akramkhan29@gmail.com

\section{https://doi.org/10.46607/iamj4409072021}

(Published Online: July 2021)

Open Access

(C) International Ayurvedic Medical Journal, India 2021

Article Received: 22/06//2021 - Peer Reviewed: 25/06/2021 - Accepted for Publication: 06/07/2021

\section{Check for updates}

\begin{abstract}
Ayurveda the science of life, healthy and higher longevity are always desirable from it. In today's modern era due to atmosphere, lack of proper healthy diet, travelling and old age etc. metabolic and degenerative disease of connective tissue and the joint problem is quite affluent, and the disease occurrence starts early. Sandhigatavata (Osteoarthritis) is a disease due to vitiated Vata in various Sandhi or joints in the body. It is described under Vatavyadhi in almost every literature of Ayurveda. Clinically the description of Sandhigata Vata explained in the classical texts is like the condition osteoarthritis in modern science. Sandhigata Vata is described under Vatavyadhi in all the Samhitas and Sangraha Granthas. Ayurveda highlighted degenerative diseases under the concepts like "Dhatu Saithilyam" and "Dhatu Kshayam". Sandhigata Vata is one such disease, which needs a specific target of therapeutic intervention to check or slow down the process of "Dhatu Kshaya" and to pacify Vata. Sandhigatavata may be correlated with degenerative joint disease or Osteoarthritis, which in turn cripples the patient to the maximum, extends and reduces the total working capacity of the person. It limits everyday activities such as walking, dressing, bathing etc., thus making individuals handicapped.
\end{abstract}

Keywords: Sandhigatavata, Osteoarthritis, Joint, Vata Vyadhi. 


\section{INTRODUCTION}

In today's modernized era, everyone is busy living life under stress, constantly running to match with the pace of this era. Osteoarthritis (OA) is the most common type of arthritis. Its high prevalence, especially in the elderly, and the high rate of disability related to disease make it a leading cause of disability in the elderly. Osteoarthritis (OA) is the second most common rheumatologic problem in India and has a prevalence rate of $22-39 \%{ }^{[1][2]}$. It is characterized primarily by articular cartilage degeneration and a secondary periarticular bone response. Because obesity, a major risk factor, are increasing in prevalence, the occurrence of osteoarthritis is on the rise. OA is a joint failure, a disease in which all structures of the joint have undergone pathologic change, often in concert. Due to continuous changes in lifestyle, overexertion, improper and disturbed dietary habits, excessive travelling, improper working and sleeping schedules, as well as improper application of Ritucharya (Seasonal regimen) and Dinacharya (Daily regimen) and likewise other factors leads to vitiation of Vata Dosha. This vitiation of Vata leads to the production of several diseases and Sandhigatavata is one of them Now a day, this disease is having high prevalence and becoming a significant threat to the working population. In Sandhigatavata, the deformity occurs in Sandhi i.e. joints. Janu sandhi i.e. Knee joint is one of the most affected joints in Sandhigatavata. Since OA (Sandhigatavata) is the most commonly disturbing joint disease but still no permanent relief is available in modern sciences and the same is still under research works. In modern medical science, mainly analgesics, antiinflammatory drugs or surgery are the options for the treatment of Osteoarthritis, which provide symptomatic relief, but also become the causative factor for adverse effects. So, the present review helps the understand the disease of the modern era through the Ayurvedic approach and help in the integrative approach in the treatment of Sandhigata Vata or osteoarthritis.

\section{Aim and Objectives:}

- To review Nidanapanchaka (causative factor) of Sandhigatavata.

- To understand Osteoarthritis in terms of Ayurveda.

\section{Objectives:}

Reviewing various literature related to Sandhigata Vata and its management.

\section{Material and Methods}

\section{Etymology}

The term Sandhigatavata (Osteoarthritis) has its origin from a combination of three words: First Sandhi means Joints, the second one is Gata means located and the third one is Vata means Vatadosha. So Sandhigatavata (Osteoarthritis) is the provoked Vata located in Sandhi. Osteoarthritis is derived from the prefix osteo means "bone" combined with arthr means "joint" and it is the latter suffix having come to be associated withinflammation.

\section{Synonyms}

No synonym of Sandhigatavata (Osteoarthritis) is given in Ayurvedic classics. However, the probable synonyms of Sandhigatavata (Osteoarthritis) used in the contexts or considered by the commentator equivalent to Sandhigatavata (Osteoarthritis) are as follows.

- Sandhigata Anila (Cha.Chi.28/37)

- Sandhivata (Bhavaprakash)

- Khuddavata (Cha.Chi.29/11)

- VataKhuddata (Cha.Chi.29/11)

- GulphaVata (Chakrapani)

- VataKantaka (Su.Ni.1/79)

Synonyms of Osteoarthritis are degenerative arthritis and degenerative joint disease (DJD).

\section{Classification:}

No reference is available for the classification of Sandhigatavata (Osteoarthritis). As Sandhigatavata (Osteoarthritis) is a Vatavyadhi, it mainly occurs due to Prakopa of Vata and so it can be classified in three typesas below.

- Dhatukshyajanya (Depletion of body tissues)

- Vataprakopaka Nidana Sevanajanya

- Avaranjanya (Covering) 
Sandhigatavata (Osteoarthritis) can be classified according to its Nidana (causative factor) - Nija, and AgantujaNija Sandhigatavata

Agantuja Sandhigatavata (Traumatic)

Several classification systems are used for the gradation of osteoarthritis:

- WOMAC scale ${ }^{[5]}$, based on pain, stiffness, and functional limitation.

- Kellgren-Lawrence grading scale ${ }^{[6]}$ especially for the knee joint.

- Tonnis classification ${ }^{[7]}$ for the hip joint,

Osteoarthritis can be classified into either primary or secondary ${ }^{[8]}$ depending on whether or not there is an identifiable underlying cause. Different categories of Osteoarthritis based on the joint affected:

- Hand

- Wrist (wrist osteoarthritis)

- The vertebral column (spondylosis).

- Hip osteoarthritis.

- Knee osteoarthritis.

\section{Nidanapanchaka Or Pathogenesis:}

Nidan There is no specific description about Hetu of the disease Sandhigat Vata. as it is one of the Vatvyadhi, the Hetu of the Vatvyadhi are to be accepted as the Hetu of the Vatvyadhi.

General Hetu of Vatvyadhi ${ }^{[9]}$ :

1. Aaharaja Hetu

2. Viharaja Hetu

> Aaharaja-Hetu: Acharya Charaka has told that Ruksha (dry), Sheet (cold), Alpa (in small quantity), Laghu (light diet), Agnimandya, Tikta, Katu, Kashay Rasatmaka Aahara (diet) is responsible for the Vataprakop which leads to the formation of Vatvyadhi.

> Viharaja-Hetu. Viharaja-Hetu also plays an important role in the production of SandhigatVata. Laghan (starvation), Plawan (swimming), Ativyayam(excessive exercise), Atimaithuna (excessive sexual activity), Mala Mutra Rasadi Dhatukshaya, Diwaswap (daydreaming), RatriJagran (Insomnia), Datukshya, Aaghat (accidental fall) Vegadharana are included in Vihara Hetus.

Samprapti (Pathogenesis) ${ }^{[10]}$

Acharyas have described the following Samprapati of the disease Sandhigatavata.

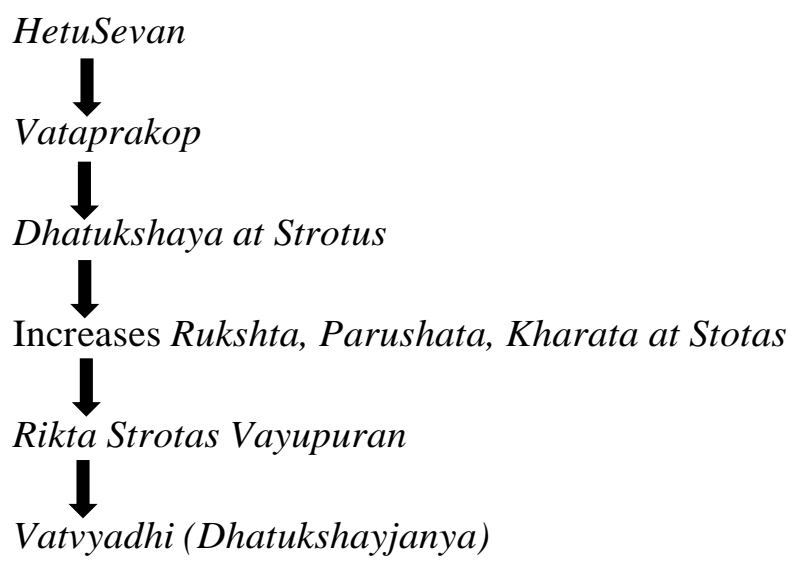

Samprapti Ghatakas: Samprapti Ghatakas of Sandhigatavata

- Nidana: Vata Prakopaka Nidana

- Dosha: Vata esp. Vyanavayu, Shleshaka

Kapha

- Dushya: Asthi, Majja, Meda

- Srotas: Asthivaha, Majjavaha and / or

Medovaha

- Srotodusti: Sanga

- Agni: Mandagni

- Dosha Marga: Marmasthi Sandhi

- Roga Marga: Madhyam

- Udbhavasthana: Pakvashaya

- Vyaktasthana: Asthi-Sandhi

Purvarupa $^{[9]}$ There is no classical description regarding the Purvarupa of Sandhigatavata, 'Avyaktanam Lakshana' of Vatvyadhi

Rupa $^{[12]}$ Rupa of Vatvyadhi, according to different Ayurvedic classics areas -

> Bhedoparvasti Sandhi Shool (joint pain)

$>$ Vatpurnadrutisparsh

$>$ Shoth (swelling)

> Prasarna-Kunchnayo Pravruttisch Svedana (pain during moment)

$>$ Atop (crepitation)

$>$ Hantisandhigat (degenerative changes at joints)

$>$ Mans-balkshyam

$>$ Astishosha (osteoporosis)

Sadhya Asadhyata ${ }^{[9]}$ :

If Sandhigata vat is occurred newly, having strong 
immunity not making any complication then it is Sadhya. Otherwise, it is Krichha Sadhya. Moreover, if there is a dominance of the Vata Dosha \& patients develop a complication of Vatvyadhi then it is Yapya.

\section{Differential-diagnosis: ${ }^{[15]}$}

Sandhishool which are present in Sandhigatavata have been also described in other diseased conditions which are as follows - - Aamvata-along this Jwaranubhuti also - Majjagatvata - Third Vega of Visha - RaktavritaVata-Sama Sannipataja Jvara

\section{Pathya-Apathya:}

Pathya Aahar and Vihar [9]: Sarpi, Tail, Vasa, Majjaseven, Snigdha, Guruaahar, Sek, Abhyang (massage), Basti (enema), Payas, Madhur, Aamla, lawanrasatmaka Aahar Seven. Apathya: Katu, Tikta, Laghu, Atichinta, Ativyayam etc.

Treatment: ${ }^{[14]}$

In Ayurveda, the treatment of Sandhigatavata is aimed at reducing the Vata Dosha and increasing the Shleshaka kapha so that the joint spaces are adequately lubricated for the free movement of the joints. For this many procedures have been mentioned like Snehana, Swedana, Mridu Samshodhana, Basti and Vatahara Aushadha, Ahara and Vihara. In some cases, practices like Upanaha, Agnikarma, Bandhana, Mardhana etc are also described. Sandhigata Vata may be correlated with degenerative joint disease or Osteoarthritis, which in turn cripples the patient to the maximum, extends and reduces the total working capacity of the person. In the modern system of medicine, the treatment adopted for osteoarthritis includes the administration of anti-inflammatory drugs, analgesics for pain relief. In many extreme cases, some surgical procedures like joint replacements are also adopted.

Drugs that proved clinically effective in osteoarthritis: There are so many drugs are mentioned in Ayurveda that is said to be having Vata Hara property and are useful for the treatment of all types of Vata disorders. But a few drugs are typically useful for the treatment of joint disorders. They are as follows:
1. Nirgundi (Vitex negundo L. - Verbenaceae) [15]

2. Eranda (Ricinus communis L. - Euphorbiaceae). ${ }^{[15], 16]}$

3. Koranta (Barleria prionitis L. - Acanthaceae). ${ }^{[17]}$

4. Bala (Sida cordifolia L. - Malvaceae)

5. Vishwa (Zingiber officinale Roscoe. - Zingiberaceae) ${ }^{[15][18]}$

\section{MODERN REVIEW OF OSTEOARTHRITIS:}

Osteoarthritis (OA) Osteoarthritis is an abnormality of synovial joints characterized by softening splitting and fragmentation (Fibrillation) of articular cartilage not attributable to direct contact with inflammatory tissue ${ }^{[19]}$. This is usually accompanied by subchondral sclerosis and bone cysts, joints space narrowing and bony overgrowth at tissue joints margins. (osteophytes)

\section{ETIOLOGY}

a) Age is a major risk factor.

b) Race hip OA is less common in Chinese and Asians than in those of western origin, whereas knee osteoarthritis is more common in Afro- Caribbean.

c) Genetic predisposition clinical evidence of inheritance of OA.

$>$ Heberden' nodes are more common in sisters of affected women.

$>20 \%$ of individuals with osteoarthritis have a positive family history.

$>$ The first-degree relative are at a twofold risk of generalized radiological osteoarthritis.

$>$ There is greeter concordance in identical twins at several joint sites.

$>$ Heritability of radiological knee and hand osteoarthritis is $40-65 \%$.

d) Gender and hormonal factors- below 45 years, the disease in whom it usually involves one or two joints, above 55 years, it is more common in women, usually involving several joints.

e) Obesity- the relationship is stronger in women than men and is strongest at the knee.

f) Other systemic factors- in women a significant association between hand disease and elevated serum cholesterol levels. Hypertension has been associated 
with generalized osteoarthritis in nonobese women. Trauma is associated with the development of osteoarthritis.

PATHOGENESIS ${ }^{[20]}$ : The earliest changes of OA may begin in cartilage. The two major components of cartilages are type 2 collagen, which provides tensile strength, and aggrecan, proteoglycan. OA cartilage is characterized by gradual depletion of aggrecan, the unfurling of the collagen matrix, and loss of type 2 collagen, which leads to increased vulnerability.

\section{CLINICAL-MANIFESTATIONS:}

OA can affect almost any joint but usually occurs in weight-bearing and frequently used joints such as the knee, hip, spine, and hands. The hand joints that are typically affected are the distal interphalangeal (DIP), proximal interphalangeal (PIP), or first carpometacarpal (thumb base); metacarpophalangeal joint involvement is rare.

\section{Symptom}

Use-related pain acting one or a few joints (rest and nocturnal pain less common)

$>$ Stiffness after rest or in the morning may occur but is usually brief ( $<30 \mathrm{~min}$ )

$>$ Loss of joint movement or functional limitation Joint instability

$>$ Joint deformity

> Joint crepitation ("crackling") 1. PhysicalExamination

$>$ Chronic monoarthritis or asymmetric oligo/polyarthritis

> Firm or "bony" swellings of the joint margins, e.g., Heberden's nodes (hand DIP) or Bouchard's nodes (hand PIP)

$>$ Mild synovitis with a cool effusion can occur but is uncommon.

> Crepitant-audible creaking or crackling of joint on passive or active movement.

$>$ Deformity, e.g., OA of the knee may involve medial, lateral, or patella-femoral compartments resulting invarus or valgus deformities.

$>$ Restriction of movement, e.g., limitation of internal rotation of the hip

$>$ Objective neurologic abnormalities may be seen with spine involvement (may affect intervertebral disks, apophyseal joints, and paraspinal ligaments)

\section{CONCLUSION}

Sandhigatvata is well explained in Ayurvedic Samhita. That ancient knowledge of Ayurveda will help in the diagnosis and management Sandhigata Vata in the present era very well. So, it is an attempt to highlighting details of Sandhigat Vata and osteoarthritis.

\section{REFERENCES}

1. www.ncbi.nlm.nih.gov

2. $1 *$ Dr. Singh Shailendra Kumar, 2Dr. Pravesh Kumar and 3Ashok Kumar, REVIEW AND EMPIRICAL PAPER ON SANDHIGATA VATA, Review Article ISSN-2455-3301, Wjpmr https://doi.org/10.47223/IRJAY.2021.4318

3. Kohn, M. D., Sassoon, A. A., \& Fernando, N. D. (2016). Classifications in Brief: KellgrenLawrence Classification of Osteoarthritis. Clinical orthopaedics and related research, 474(8), 1886-1893

4. Kovalenko, B., Bremjit, P., \& Fernando, N. (2018). Classifications in Brief: Tönnis Classification of Hip Osteoarthritis. Clinical orthopaedics and related research, 476(8), 1680-1684

5. TrikamjiYadavji, Commentary Ayurvedadipika of Cakrapanidatta on Caraka samhita of Agnivesa, Chiktsa Sthana; Vatavyadhichiktsa adhayaya: Chapter 28, Verse 15-17, Varanasi: Chowkhambha Surbharati Prakashan, 2017; 617.

6. Kovalenko, B., Bremjit, P., \& Fernando, N. (2018). Classifications in Brief: Tönnis Classification of HipOsteoarthritis. Clinical orthopaedics and related research, 476(8), 1680-1684

7. Dr Brahmanada Tripathi, Charak Samhita of Maharshicharak, Chukhambhaprakashan, Varanasi, 2011, Chikitsastan, chapter 28.

8. Astang- Hrudayam by kavirajatridevgupt, Nidan-stan chapter no.15verse no.5-6 page no. 375

9. "Sandhigata Vata" A Disease Of Modern Era: A Conceptual Review Patel Satya Prakash1, Yadav Sujata2

10. DISEASES IN AYURVEDA- An android book by Vd. Arun S. Dudmal (M.D) An android book chapter no 29,30

11. A review on Sandhigatavata and its Management Principles Review Article Nagesh Gandagi1*, Shub- 
hangiPatil2 ISSN: 0976-5921

12. Neha Navalchand Jain et al: A Short Review On Sandhigat Vata W.S.R. To Osteoarthritis ISSN: 23205091

13. Nirmal $P$ et.al, Influence of six medicinal herbs on collagenase induced osteoarthritis in rats. Am J Chin Med. 2013;41(6):1407-25.

14. Medhi B, Kishore K, Singh U, Seth SD. A comparative clinical trial of castor oil and diclofenac sodium in patients with osteoarthritis.Phytother Res. 2009 Oct;23(10):1469-73. DOI: 10.1002/ptr.2804.

15. Singh B et.al., Anti-inflammatory activity of 'TAF' an active fraction from the plant Barleria prionitis Linn. J Ethnopharmacol. 2003 Apr;85(23):187-93.

16. Paramdeep G.Efficacy and tolerability of ginger (Zingiber officinale) in patients of osteoarthritis of the knee.Indian J Physiol Pharmacol. 2013 AprJun;57(2):177-83

17. Golawalla's MEDICINE FOR STUDENTS 22nd edition: 2008, Rheumatology chapter page no.1047

18. Dennis L. Kasper et al. 19th edition Harrison's manual of medicine chapter 163 osteoarthritis page no. 861

19. Shubham Puri, B. S. Savadi. A Comparative Study on Agnikarma and Indigenous Drugs in the Management of Janu Sandhigata Vata w.s.r. to Osteoarthritis of Knee Joint. International Journal of Ayurveda and Pharma Research. 2019;7(1):39-44.

20. Shastri R, Upadhaya Y, editors. Charaka Samhita of Agnivesha, Chikitsa Sthana, Ch. 28, Ver. 37, Edition reprint. Varanasi: Chaukhambha Bharti Academy; 2007. p. 783.

\section{Source of Support: Nil Conflict of Interest: None Declared}

How to cite this URL: C. S. Tanmane \& Akram Yusuf Khan: Review Article On Ayurvedic Approach Sandhigat Vata W.S.R. To Osteoarthritis. International Ayurvedic Medical Journal \{online\} 2021 \{cited July 2021\} Available from: http://www.iamj.in/posts/images/upload/1882_1887.pdf 